University of Nebraska - Lincoln

DigitalCommons@University of Nebraska - Lincoln

Faculty Publications from the Harold W. Manter Laboratory of Parasitology

$12-1974$

\title{
A Possible Function of the Fibrillar Coat in Acanthocephalus jacksoni Eggs
}

\author{
David F. Oetinger \\ University of Nebraska - Lincoln \\ Brent B. Nickol \\ University of Nebraska - Lincoln, bnickol1@unl.edu
}

Follow this and additional works at: https://digitalcommons.unl.edu/parasitologyfacpubs

Part of the Parasitology Commons

Oetinger, David F. and Nickol, Brent B., "A Possible Function of the Fibrillar Coat in Acanthocephalus jacksoni Eggs" (1974). Faculty Publications from the Harold W. Manter Laboratory of Parasitology. 361. https://digitalcommons.unl.edu/parasitologyfacpubs/361

This Article is brought to you for free and open access by the Parasitology, Harold W. Manter Laboratory of at DigitalCommons@University of Nebraska - Lincoln. It has been accepted for inclusion in Faculty Publications from the Harold W. Manter Laboratory of Parasitology by an authorized administrator of DigitalCommons@University of Nebraska - Lincoln. 


\section{A Possible Function of the Fibrillar Coat in Acanthocephalus jacksoni Eggs}

Eggs of many acanthocephalan species possess filaments entwined under the outer, bounding membrane. Whitfield (1973, Parasitology 66: 387-403) listed some of the species for which these filaments have been reported. Monné and Hönig (1954, Ark. Zool. Ser. 2 7: 257-260) described physical and chemical properties of filaments in the eggs of Polymorphus botulus and P. minutus; Stranack (1972, Parasitology 64: 187-190) and Whitfield (1973, loc. cit.) have described ultrastructure of the filaments from other acanthocephalan species. Filaments were first described in Acanthocephalus jacksoni eggs by Bullock (1962, J. Parasit. 48: 442-451). West (J. Parasit. 50: 731-734) further described filaments in A. jacksoni eggs and postulated that a fibrillar coat is a component of the envelope series of all acanthocephalan eggs. In some forms, however, he recognized that modification occurs. He thought that the shell of terrestrial species is homologous to the fibril- lar coat. With this possible exception, there is no published hypothesis of a function for the fibrillar coat.

In examining suspensions of A. jacksoni eggs, it was noted that the outer membranes were lacking and that most of the eggs were in clusters of five to 10 eggs, united by slender, threadlike filaments (Fig. 1). No such filaments have been previously reported on the outside of acanthocephalan eggs. These filaments proved to be portions of the fibrillar coat which were apparently released upon loss of the outer membrane. Each egg possessed two slender, tapering filaments, $700 \mu$ long, attached to the remainder of the fibrillar coat at the level of the anterior end of the acanthor.

Membranes as described by West (1964, loc. cit.) were present and intact in eggs examined soon after collection from intestinal debris of infected fish (Fig. 2). In an attempt to identify the cause of the outer membrane's loss, intact eggs were treated in water from the

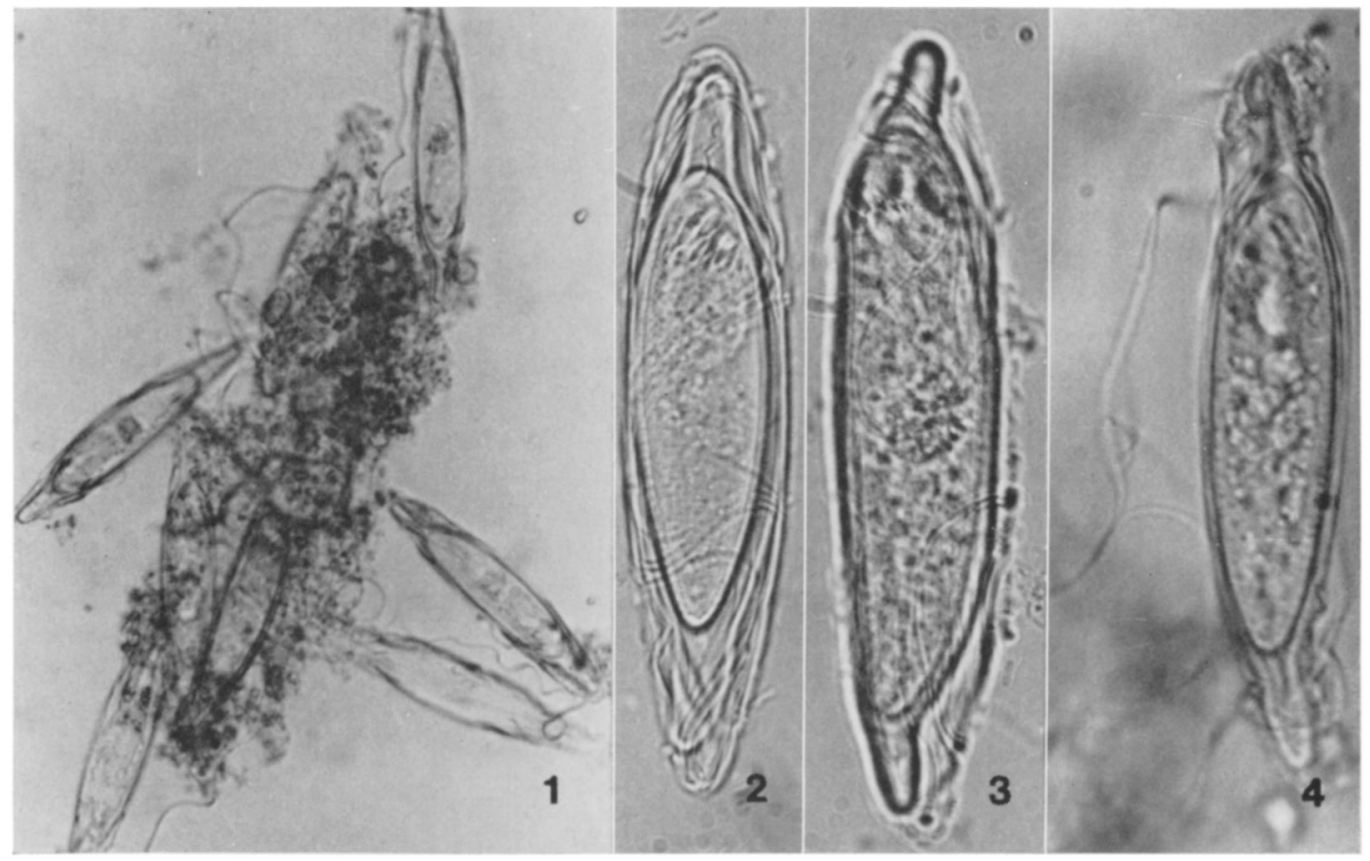

Figures 1-4. Photomicrographs of Acanthocephalus jacksoni eggs. 1. Eight eggs united by filaments. $\times$ 300. 2. Intact egg. $\times 800$. 3. Egg without outer membrane; filaments still adhering to fibrillar coat. $\times$ 900. 4. Egg with filaments extending from fibrillar coat. $\times 800$. 
fish's habitat, artificial pond water (specific gravity 1.000), tap water (specific gravity 1.000 ), distilled water (specific gravity 1.000), and Ringer's solution for poikilotherms (specific gravity 1.008) each at pH's from 4 to 10 . After an hour the outer membranes were still intact in eggs from each solution. Untreated eggs were stored at $4 \mathrm{C}$ in a suspension of intestinal debris and pond water. During storage bacterial and protozoan concentrations increased noticeably in the suspension. Although the outer membrane was still intact in most eggs after storage for 3 days, it had been lost in some. Individual eggs were then studied microscopically for up to $3 \mathrm{hr}$. It was observed that bacteria and small ciliates have an affinity for the eggs and are capable of eliminating the outer membrane (Fig. 3) and releasing the filaments (Fig. 4). Eggs were not further attacked even after storage for 6 months.

It is not known whether, in nature, bacteria and protozoans destroy the outer membrane releasing filaments before ingestion by the isopod intermediate host or if the outer membrane is lost in the alimentary canal of the intermediate host. In either event, filaments of the fibrillar coat of acanthocephalan eggs seem to function in entangling and clumping much in the same manner as do those of monogenetic trematode eggs. Among acanthocephalans, filaments could result in clumping of eggs enhancing infection of the intermediate host or they might retard passage through the isopod alimentary canal giving acanthors additional time in which to hatch.

We are indebted to Mr. Patrick Muzzall and Dr. Francis C. Rabalais, Bowling Green State University, Ohio, for supplying suspensions of A. jacksoni eggs.

David F. Oetinger and Brent B. Nickol, School of Life Sciences, University of Nebraska-Lincoln, Lincoln, Nebraska 68508

\section{Intestinal Phase of Trichinella spiralis in Congenitally Athymic (Nude) Mice}

In a Trichinella spiralis infection both a humoral and cell-mediated type of immunity is provoked (Catty, 1969, Monogr. Allergy 5, S. Karger, Basel; Ruitenberg and Duyzings, 1972, J. Comp. Path. 82: 401-407). Although the humoral response is more marked, this does not necessarily imply that this type of immunity is more important for host protection. At least a part of the immunological response is functional, i.e., deleterious to one of more phases of the parasite.

The adult worms (the intestinal phase) are subject to the immunological defense mechanism of their host, the expression of this immunological reaction being the expulsion of the adult worms from the intestinal tract. In neonatally thymectomized rats and rats treated with antilymphocyte serum (ALS) or anti-thymus cells serum (ATS) a distinct prolongation of the intestinal phase was observed (Ruitenberg, in press, Proc. III Int. Conf. on Trichinellosis, Miami, 2-4 Nov. 1972; Gore et al., 1970, J. Parasit. 56: 122). Since removal or elimination of the pool of thymus-derived $(\mathrm{T})$ cells resulted in abrogation of host-protective immunity it was suggested that the functional antigens of T. spiralis are thymus-dependent (Ruitenberg, in press, Proc. III Int. Conf. on Trichinellosis, Miami, 2-4 Nov. 1972).

Neonatally thymectomized animals are likely to have a certain number of thymus-processed cells as was described for mice (Raff and Wortis, 1970, Immunology 18: 931-942). The same is presumably true for ATS-treated animals. Therefore, it seemed worthwhile to study the intestinal phase of $T$. spiralis in congenitally athymic (nude) mice. The recessive gene nude $(n u)$ (Flanagan, 1966, Genet. Res. (Camb.) 8: 295-309) is associated with hairlessness and congenital aplasia of the thymus in mice (Pantelouris, 1968, Nature 217: 370371). The immune response of $n u / n u$ mice is comparable to that in neonatally thymectomized rodents. Thus cell-mediated responses and antibody formation against various antigens are profoundly impaired (Rygaard, 1969, Acta Pathol. Microbiol. Scand. 77: 761-762; Reed and Jutila, 1972, Proc. Soc. Exp. Biol. Med. 139: 1234-1237), while the antibody response to the thymus-independent antigens Esche- 